\title{
Translator's Foreword
}

This is not a book about opera, or even strictly "about" music. It is rather a timely meditation on music-specifically the lyric mode of opera-as a site for discussion of the more general aesthetic program called Wagnerism. Sounding philosophy's dialogue-or lack of one-with music, Lacoue-Labarthe opens up a new space for consideration of the lyric subject, music and representation, ${ }^{1}$ and what he has elsewhere called the "fiction" of the political. These issues, treated here in specific historical sequence and precise philosophical context, are still with us.

Opera is, once again, flourishing in the West, with opera houses filling in what John Rockwell has recently called the "black holes" in "the nearly unbroken sweep of operatic history from 1600 to modernity." 2 Aficionados say that opera's currency has never waned, but new productions and new opera houses in France illustrate opera's regained predominance. Projects within the Ministry of Culture and without have focused on producing and promoting the French repertory, and less frequently performed French works from the baroque to the twentieth century are now being

I. For work on this dialogue inspired by Lacoue-Labarthe, see Susan Bernstein, "Fear of Music? Nietzsche's Double Vision of the 'Musical Feminine," in Peter J. Burgard, ed., Nietzsche and the Feminine (Charlottesville: University Press of Virginia, 1994).

2. New York Times, 27 December 1993, I(B). 
staged by French and non-French directors. Nowhere is this resurgence of opera so apparent as in the Place de la Bastille, one of the cultural foci of Paris in the last decade and the site of perhaps the most audacious of the government's Grands Travaux, the Opéra de la Bastille. Planting a new opera house in one of the most popular and animated quarters of Paris means assuming that opera still defines a political style as much as museums, libraries, and grand arches do; it means assuming that opera is still at the center of people's lives and that it still carries a social and political charge. "750,000 spectators will go to the Paris Opéra next season," reads the 1993-94 season's advertisement; "Why not you?" Not since Louis-Désiré Véron, director of the Paris Opéra after the July Revolution of 1830 , heightened demand for tickets by turning would-be buyers away from the box office, certain of their redoubled return, has the attempt to build an audience through the strategies of mimetism been so apparent. The 1993-94 season opened with a production of Wagner's Flying Dutchman directed by Werner Herzog, and this season Paris awaits the first Ring cycle to be staged there in years.

Although this is not a book "about" Wagner, music practice does, in fact, hold a place here. Lacoue-Labarthe is both music lover and philosopher; the progression of scenes charts LacoueLabarthe's own course, as he notes in his preface. When asked what place Wagner held in his musical taste before the critical distance developed and analyzed in Chapters 2, 3, and 4, the author describes the same emotional investment of Baudelaire in Chapter I: "I made the pilgrimage" to Bayreuth. Baudelaire's passion for Wagner's music is not, then, criticized in retrospect but weighed in context, in much the same way that the educated opera lover may reject Wagner's writing but is always moved by one motif or another.

Thus, scenes that replay those made over or about Wagner and studied in this book surface in today's music world, with variations or reversals worth noting.

$\$$ Nineteenth-century literature in thrall to musical form is the image created by Baudelaire's reaction to Wagner: "In you I found every- 
thing-I found myself." Institutionalized in literary study via Walter Pater's fin-de-siècle formulation about the arts constantly aspiring to the condition of music, this trend is reversed in late-twentieth-century academic discussion between literary theorists and musicologists, in which the critical discourse of theory becomes the language both sides seek to speak, as if all arts were now aspiring to the condition of theory.

$\$$ The Metropolitan Opera in New York, the last holdout among opera houses in this country, considers giving in to the trend of projecting supertitles above the stage, despite arguments that it takes attention away from the performance and divides the audience by causing those who do not know the libretto to laugh at the wrong time. Met conductor James Levine, himself a performer (at one concert he changed costume six times for the six Brandenburg concerti), says, "Over my dead body will they show those things at this house. I cannot imagine not wanting the audience riveted on the performers at every moment." 3

$\S$ Loaded with nineteenth-century connotation, "opera" becomes a bad word for some composers; asked if he will write another opera (after Le Grand Macabre, almost exclusively performed as a concert opera), Transylvanian composer György Ligeti says "No, not an opera. Maybe something I would call a music-drama." Opera in every way but in name. But if "opera" is a bad word for this sometime Hungarian, sometime Romanian composer now living in Hamburg, it is not so for Herbert Zipper, a composer and conductor born in Austria roughly a generation before Ligeti. National Socialism confiscated and destroyed his music and sent the composer to Dachau, but it could not destroy the musical impulse. ${ }^{4} \mathrm{~A}$ few pieces preserved by copyists and pupils-but more significantly the political activism through music education which has been his life's work in Dachau, in the United States, the Philippines, Europe, and China-provide an alternative example of the continuing power of music both against historical politics and within political history.

$\$$ And finally, in an interesting take on the "caesura" of Hölderin cited by Adorno to speak about Schönberg's Moses and Aaron, Lacoue-

3. New York Times, 20 August 1993, I(A), 6(B).

4. See Paul Cummins, Dachau Song (Peter Lang, 1993). 
Labarthe told the following anecdote in a 1990 seminar. Discussing another form of music Lacoue-Labarthe himself both admires and plays, he described Miles Davis performing shortly before his death and stopping, midphrase, to utter an expletive. "He was working," Lacoue-Labarthe explained. In the caesura not of speech but of music, filling in with an empty word for a musical phrase he could not find, Miles shows how music is simultaneously inside the body, of the subject, and beyond. 